\title{
Unconventional Solutions for Unconventional Threats: The Changing Role of The Chinese Media in the War on HIV/AIDS
}

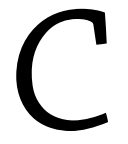

hinese health officials have predicted that about ten million individuals in China will contract HIV by 2010 (Yang 2002). But despite this potential threat the government continues censoring the media's coverage of HIV, thus hindering public health efforts aimed at providing information to those who could benefit from it. ${ }^{2}$ As the first and most important health-related threat for which the scientific community still lacks a cure, the HIV/AIDS pandemic will continue to be a top priority for the countries of the Pacific Rim in the foreseeable future. Although it contains the most dynamic and economically successful countries of the world, the region also includes the nations with the highest HIV/AIDS infection rates, China and India. This demonstrates the inefficacy of borders and traditional military responses in controlling the spread of an alarming security threat. This situation makes cooperation among members of the Pacific Rim more urgent, for it means a

1. Profesor del Departamento de Estudios Internacionales del Pacífico, Universidad de California, San Diego. Miembro del Servicio Exterior Mexicano.

2. In 2007, the United Nations Program on HIV/AIDS (UNAIDS) reduced its estimate of people living with HIV in India and five Sub-Saharan countries (Angola, Kenya, Mozambique, Nigeria, and Zimbabwe) which accounted for a $16 \%$ reduction from the original estimates for 2006. Despite the refinement of methodologies to assess the level of the crisis, the global prevalence of HIV infection is remaining at the same level, including the trends predicted for China (UNAIDS 2007: 4). 
common vulnerability that can only be checked by the adoption of successful strategies implemented in other countries of the area ${ }^{3}$.

Focusing in one of the countries where the AIDS pandemic will have specially devastating consequences, this paper addresses the question of whether the Chinese media will adopt a critical approach to reporting HIV/ AIDS cases, and to what extent they will be able to prevent a humanitarian catastrophe. I argue that as long as the Chinese news media remain under the dual pressure of the state control and the profit-orientation, the likelihood of increasing HIV coverage will be very low, and thus no sort of socially responsible media will emerge. As a result, only alternative media formats (soap operas, TV commercials, documentaries) could start filling the ignorance gap that prevails in Chinese society because they reach broader audiences and utilize powerful messages. The paper concludes that if the Chinese government wants to reduce criticism and win the battle against HIV, it would be wise for them to allow these formats to promote the message now, given its proven effectiveness in behavioral change.

The article is divided in six sections: a track of the virus's inception and evolution in China is provided in the first section; chapter two contains a review of communication science's main arguments for considering mass media a key weapon to combat the spread of HIV/AIDS; a description of the Chinese media's coverage of the epidemic defying this mainstream line of thought is the content of the third section. Chapter four analyzes the reasons behind the Chinese government censorship of HIV-related news and the tools it uses to "prevent" dissent; while section five details exemplary cases of brave journalists that report HIV/AIDS cases against the party line by taking advantage of new media formats. Finally, chapter six summarizes the findings, and most importantly, allocates responsibilities in a humanitarian crisis where taking no side is no near possible.

3. By the time this paper was about to be concluded, Chinese authorities lifted an anachronistic two-decade ban on travel to the mainland by HIV-positive people. This measure, together with a similar American ban finally dropped in January 2010, was worldwide criticized for being rooted in fear rather than fact (Wines 2010). While it is too early to know the State Council's rationale for this decision, it can be inferred that the Chinese leadership finally acknowledged the inefficacy of border controls in halting a pandemic mostly driven by its own population's behavior. 


\section{The Quiet Pace of China's New Security Threat}

Although the first HIV cases in China were detected in the mid 1980s, the epidemic's rapid spread occurred in the 1990s in the Yunnan province. The Yunnan's HIV outbreak was not accidental. As part of the Golden Triangle (including Thailand and Laos), the southern Chinese province shared the area's most striking feature: nowhere in the world was the reservoir of infected drug users and commercial sex workers higher (Brown et. al. 1994; Hwang 2001). This means that the likelihood of being infected with HIV among the firsttime consumers of heroin or commercial sex was very high -if not a matter of course- because needles and sex workers were in limited supply and presumably all infected. The low number of needles was the result of a ban on blood products imposed in 1985, whereas the shortage of commercial sex workers responded both to the cultural environment where women are expected to be virgins at marriage and the gender imbalance caused by the one-child policy. ${ }^{4}$ Given the early stage of the epidemic, only a few AIDS cases were reported and the disease

As long as the Chinese news media remain under the dual pressure of the state control and the profitorientation, the likelihood of increasing HIV coverage will be very low, and thus no sort of socially responsible media will emerge expanded quietly through sexual contact or via needle-sharing. As Huang states, the low confirmed cases were no help in convincing the central leaders how serious the problem was, so government inaction followed (2005: 6).

At the time the Yunnan HIV crisis was about to explode, the epidemic hit the Henan province with similar consequences. In the 1990s, approximately one million people were infected with HIV through careless practices at blood collection centers run by the local health department as well as illegal blood

4. The deeply ingrained cultural preference for male children remains as a contributing factor to the spread of HIV. The consequent dearth of available brides fuels demand for commercial sex workers, helps accelerate male migration into cities, and increases the numbers of women who are kidnapped and sold into prostitution or as "unwilling brides" (Gill et al. 2002). 
collection centers. Infections occurred when the blood remaining after extraction of the plasma was combined and re-injected into the original donors (HRW 2003). The reason behind these health officials' outrageous decision was financial: they were trying to take advantage of the highly profitable global demand for blood plasma. Chinese government documents now reveal that Henan was just one of seven central Chinese provinces where similar blood collection practices fueled the spread of HIV/AIDS. To date no government official has been prosecuted for the scandal and therefore HIV prevalence in China is potentially larger than the state has yet acknowledged.

Currently, the most important vehicles of HIV in China are unprotected sexual intercourse and needle sharing among intravenous drugs' users -IDU- ${ }^{5}$ (UNAIDS/WHO 2006, 2007; Ministry of Health China, 2006; Lu et al., 2006). This situation is aggravated by one the most important changes in China's post-reform era: freedom of movement has increased enormously due to the elimination of restrictions on migration from the countryside to the prosperous cities, leading to a massive group of domestic migrants commonly known as the "floating population" (Gill et. al. 2002). The floating population is largely composed of young to middle-aged men and women who are in their most sexually active stages of life. Many of its members are poorly educated or speak only non-Mandarin dialects. If these workers run into legal or financial trouble they are forced to return home and those HIV carriers can spread the infection wherever they go. In fact, as a survey carried out from September 2002 through January 2003 revealed, the pandemic's magnitude could be worse than originally predicted: almost $36 \%$ of the migrants surveyed declared never using a condom during sex, and up to $63 \%$ failed to use a condom in the last 3 sexual encounters ( $\mathrm{Li}$ 2004: 545). This is why it is very difficult to monitor, educate, and treat this group.

Other vehicles of transmission on the rise include unprotected sex among men who have sex with men $(\mathrm{MSM})^{6}$ and a resurgent commercial sex industry (Choi et al., 2007; Tao et al., 2004; Zhu et al., 2005; Choi et al., 2003; Ma et al., 2006). The virus has affected at least 1.5 million people thus far (Ministry of Health China, 2006). In fact, the numbers are probably much higher because

5. Huang estimates that between 1985 and September 2004, IDU-related transmission and commercial blood and plasma donation accounted for $43.9 \%$ and $24,1 \%$ of total HIV infections, respectively (Huang 2005: 3).

6. MSM and heterosexual transmission accounts for $11.1 \%$ and $19.8 \%$ of the total estimated cases, respectively. Huang Ibid 
local authorities have minimized the epidemic in order to protect external investment in local economies.

As Gill points out, given the aforementioned trends China will face the disastrous convergence of the three main paths of HIV transmission: from the southern border regions, the spread of HIV largely through intravenous drug use; from the eastern seaboard, the spread of HIV through sexual contact; and from the central inland provinces, the spread of HIV through illicit and unsafe blood collection (Gill et. al. 2002). If China's reluctance to act decisively in the AIDS epidemic is not reversed, it will cost lives and cause incalculable suffering to those living with the virus.

\section{The Role of Media In The War on HIV/Aids}

Communication Science describes the media cycle as the process of an event getting into the media agenda and then jumping into the policy agenda (Singhal et. al. 2003: 81). For an event to go through the whole process, it needs to be given considerable attention in order to be part of the public agenda, which is defined as the priority issues that the public perceives as important. Finally, if an issue like HIV is considered by policymakers important enough to receive funding, then the issue has climbed up to the policy agenda. These actions do not necessarily mean that the original problem is solved. Actually, after some months or years the issue may simply be pushed off the national agenda and the social problem may be gradually forgotten until the attention shifts to a new social problem.

It is precisely for this reason that the media play a decisive role in fighting against public and government apathy towards HIV/AIDS. Because of their central position in people's lives, the mass media have unrivalled potential to inform and educate the general public. However, in the response to AIDS only a tiny fraction of that potential has been tapped as demonstrated by two surveys conducted in 2000 and 2003. The former survey, sponsored by the State Family Planning Commission in Beijing, Shanghai, Heilongjiang Province and Henan Province, showed that 1400 out of 7000 respondents (or $20 \%$ ) had never heard of AIDS; $50.3 \%$ (or roughly 3500 respondents) knew that AIDS was not curable; and over $70 \%$ (or 4900 respondents) never thought of trying to prevent the spread of the disease. Of the 5600 respondents who heard of AIDS, only $22.7 \%$ (or 1271 respondents) knew AIDS is spread by a virus (Huang 2005: 4). The 2003 survey's results barely did change: $20.5 \%$ of 
commercial sex workers had never used condoms whereas a similar proportion (19\%) declared using it always (UNAIDS: 2004).

In this tragic context of widespread ignorance, my paper draws from the assumption that media have a social responsibility with the community in which it interacts and in doing so I aim to contribute to the calls of journalists and academics who pledge to keep HIV in the public eye (Settle et. al. 2005; Hebden 2006; Swain 2005; Lule 2005). According to the 2005 UNAIDS report Media and HIV/AIDS: Making a difference, mass media can make an impact by stimulating open and frank discussions on HIV/AIDS; providing a platform for those most affected by the epidemic; challenging stigma and discrimination by providing accurate information; encouraging leaders to take action; and most importantly preventing "AIDS fatigue" through a constant attention to the epidemic.

Unfortunately, the media's coverage of HIV/AIDS has been erratic for three reasons: first, because HIV deals with human behaviors shaped by deep-rooted traditions; second, because health information has to compete for broadcast time and audiences; third, because journalists typically framed the epidemic as an emergency or as a chronic disease rather than a lasting concern (Swain 2005: 259). However, as Ratzan points out,

effective health communication is our primary and most potent weapon in preventing the spread of AIDS. Until a vaccine or cure for HIV infection is discovered, communication is all we have (Ratzan 1993: 257, cited in Swain 2005: 261)

This powerful message seemed to sound the alarms in China in 2005 when the China Daily published an opinion article about the role the media plays in HIV/AIDS prevention. Citing that "According to a recent national survey, 87 per cent of $C$ hinese people consider television news programmes a reliable source of HIV/AIDS information, and up to half trust newspapers", Settle and Valentino concluded that "undoubtedly the media could be instrumental in encouraging discussion of what remains a taboo" (Settle et. al. 2005). Furthermore, as the authors accurately underlined:

ensuring interesting and ethical reporting of HIV/AIDS is no longer enough. Journalists and media institutions need to think beyond individual stories and develop an overall sustained strategy for their involvement in the struggle. The media, being strategically placed to educate, need to play a proactive and responsible role in the fight against HIV/AIDS (Settle et. al. 2005). 
While the media still debates its function in China's traditional society, these journalists' courage to circumvent a government ban for this article provides hope for a more participatory type of journalism that ideally would include, among many other things, talking about HIV/AIDS beyond December $1^{\text {st }}$, the International AIDS Day (Rosenthal 2000). As Marlene Cimons once said, "words don't kill ...but can save lives" (cited in Singhal et. al. 2003: 84).

\section{Chinese Media's Coverage of HIV}

Media coverage of HIV in China has been very poor because for many years the government's official position was denying it had a HIV/AIDS problem. At the beginning of the pandemic, Chinese health officials blamed homosexuality and promiscuity for spreading the disease but did nothing to stop it because they were convinced that none of these factors belonged to Chinese morality, let alone their illegal character. When the crisis hit Yunnan and Henan provinces, the government adopted the 1989 Law of Prevention and Treatment of Infectious Diseases that focused on eradicating the risk behavior. Under the law, any person found to be infected with HIV would be quarantined and forbidden to go to work or school. The law's punitive nature only pushed high-risk groups and activities underground, thus promoting a further spread of the disease and exacerbating public stigma and discrimination towards HIV/AIDS victims. More important, as Huang states, China's initial reaction stands out for lagging approximately 10 years behind other countries' responses (2005: 5). This changed in 2001 when the then Chinese health minister, Zhang Wenkang, acknowledged before the United Nations General Assembly Special Session on HIV/AIDS that China could have as many as 600,000 cases of HIV (Gill et. al. 2002). China's admission of the epidemic was reinforced in 2003 when the country signed an application to the Global Fund to Fight AIDS, Tuberculosis and Malaria, implicitly acknowledging the spread of HIV through unsafe blood collection centers in seven provinces, including Henan (HRW 2003).

In her seminal piece Framing AIDS in China: A Comparative Analysis of US and Chinese Wire News Coverage of HIV/AIDS in China, Min Wu stressed that different realities are constructed by the Associated Press and Xinhua agencies. Not surprisingly, the different framings of HIV/AIDS in China correspond to the different levels of independence enjoyed by the two news companies. As China's official news agency, Xinhua has constructed a positive image of the 
Chinese government in its coverage of HIV/AIDS. According to Min, Xinhua's pro-government frame is supported by three distinct frames (Min 2005: 251). The first one -the defense frame- is constructed through the extensive coverage of the Chinese government's 'open' attitude in addressing the HIV crisis, like President Hu Jintao's visit with HIV/AIDS patients at a hospital ward in 2005. The second frame, called the progress frame, essentially deals with the changes that the Chinese government and Chinese society have experienced in fighting the epidemic. Finally, through the ambivalence/ambiguity frame, Xinhua tries to reflect the Chinese government's dilemma to release an exact number of HIV cases. In this case, Xinhua's report usually de-emphasized the statistics by putting them in the middle or near the end of the news story, but adopted the official figures throughout the entire year ${ }^{7}$.

While Ma (2005), Huang (2005) and Min (2005) all recognize the effect of the SARS crisis as a wake-up call aimed at changing the government's attitude towards HIV ${ }^{8}$, the latter's conclusion is that Xinhua has reported HIV/AIDS in China mostly along the party line:

Xinhua has long been the "tongue and mouth" of the Chinese Communist Party in disseminating its message. It has focused on the "good news" about HIV/ AIDS [because] the Chinese media are instructed to downplay the magnitude of any crisis to maintain political, social and economic stability (Min 2005: 269)

While the former is true, it would be fair to recognize that the lack of critical reporting of HIV/AIDS in the Chinese media is also related to its profitorientation. Beginning in 1994, the media was reformed to enhance its own economic sustainability leading to the commercialization of its content (Bai 2006; Lewis 2004). Driven by fierce competence, tabloid journalism prefers

7. The Chinese government sustains that there are approximately 840,000 HIV-carriers, of whom 80,000 suffer from AIDS. This statement did not vary during 2005 in Xinhua's coverage of HIV/AIDS (Min 2005: 266).

8. In stark contrast to HIV/AIDS, it took only three months for the Chinese government to address the SARS epidemic that started in Guangdong. As Huang accurately states, this was due to structural differences between outbreak events like SARS, and attrition epidemics like HIV/AIDS. While the virus causing SARS is highly pathogenic and contagious, HIV's pathways of transmission are limited and relatively under one's control. Therefore, the former's potential to raise fear and anxiety in a short period of time is considerably higher than the latter's (2005: 9). The $0.7 \%$ reduction in that year's GDP is another reason for the priority given to SARS, for similar calculations with HIV/AIDS only placed the economic growth rate fall at $0.5 \%$ in a worst scenario (Huang 2005, Eberstadt 2002). 
publishing sensational news that increases sales rather than educational notes of HIV prevention (Gang 2003). In that sense, the Chinese media has not escaped the "compassion fatigue" that characterizes its western counterparts. Commercialization has also led to "performance bonuses" that are based upon the journalists' ability to please both consumers and party bosses. As Southerland states,

The need to earn bonuses, which can amount to more than half of a journalist's salary, leads reporters to engage in an approach to journalism that shuns any hard-hitting investigative journalism on issues of political sensitivity, resulting in what The Wall Street Journal once described as "new and improved propaganda" (Southerland 2007)

Acknowledging that the Chinese media has pushed its freedom of speech to the limits in certain issues like corruption and pollution, HIV/AIDS coverage could expect a similar improvement in the future. The likelihood of this to happen will depend on a decisive fight against HIV that includes penalizations for the grave malpractices of local officials together with a complete independence on the part of the mass media.

\section{The Fragile State: Explaining The Censorship of The Chinese Media}

The fact that Li Changchun, governor of Henan at the time the HIV epidemic hit the province, is in charge of propaganda at the Politburo Standing Committee of the CCP, is an indicator of the Chinese government's efforts to obstruct the media coverage of HIV/AIDS. Along with Luo Gan, the Standing Committee member who oversaw the police and security services, these two Politburo members were allied with local officials who tried to cover up the HIV/AIDS-blood plasma connection (Southerland 2007) ${ }^{9}$.

Unlike democratic governments where such malpractices end with the officials' imprisonment, the Chinese leadership opted to hide the crisis and shout at the media for the potential threat it posed to regime survival. As Shirk points out, the Chinese government's reaction to HIV/AIDS is typical of its condition as a "fragile state": the permanent state of paranoia forces

9. As the oldest member of the Politburo Standing Committee, Luo Gang retired in 2007 and Zhou Yongkang occupied his position. 
the Chinese leadership to censor bad news that could undermine the CCP rule (Shirk 2007). China's state-run media, therefore, "avoided" this issue and focused instead on the less controversial elements of HIV/AIDS -transmission of HIV infections through sex or intravenous drug use.

Control over the media includes a national registration system of all journalists and mandatory participation in ideological training sessions. Officials deliver content requirements via telephone, but also on occasion in propaganda circulars. Indirectly, government control is exerted through propaganda officials who constantly remind journalists of what they consider the most sensitive topics. The taboo list ranges from coverage of dissidents and ethnic minorities to high-level corruption and unrest among farmers and workers. In extreme cases, the Chinese government uses a vaguely worded "national secrets" law that prohibits journalists from conducting investigative reporting on sensitive issues like HIV/AIDS (Southerland 2007). Surprisingly, government censorship is not decreasing. On the contrary, it is on the rise regardless of the arrival of younger generations to the Chinese leadership. As Southerland states,

When President Hu Jintao took power more than three years ago, some Chinese intellectuals, including journalists, hoped that he would open up China's political system and allow the Chinese media to begin covering major stories such as corruption and rural unrest. Nevertheless, the media face even stricter controls under $\mathrm{Hu}$ than was the case under his predecessor Jiang Zemin. By early 2004, the honeymoon between the government and the press was over as the Communist Party began another crackdown on newspapers and television stations that dared to report on the Chinese society's "dark side" (Southerland 2007)In the short run, consequently, we cannot expect serious openness from the Chinese regime and those who speculate that a more open environment will evolve as younger leaders arrive will be disappointed.

Furthermore, the reason for a lack of HIV/AIDS coverage in the Chinese media lies in the political structure: the decentralization to provinces and counties to carry out national policies -health services included-allowed for local officials to provide these services without being checked, a situation that is reinforced by the cadre evaluation system because in order to be promoted they are evaluated according to economic targets only. Given this state of affairs, it is clear that local officials have no incentive to release unpleasant information -including HIV/AIDS infections- because that would undermi- 
ne the economic performance upon which their careers depend. Therefore, unless the Cadre Evaluation System includes performance in controlling the epidemic as a new criterion for promotions as well as credible penalizations for hindering such information, the likelihood of increasing HIV/AIDS media coverage will be very modest. Luckily recent statements that the Ministry of Health is drafting regulations to mandate accountability for officials who cover-up HIV/AIDS are very promising, provided they have the status of law and are strictly enforced ${ }^{10}$. As Human Rights Watch points out,

The challenge for China is to maintain and apply these standards to those who have been complicit in the spread of HIV, those who have covered up the AIDS epidemic, and to state actors who discriminate against people with HIV/AIDS (HRW 2003).

While this remains true, it would be fair to recognize that these measures will be unpractical unless civil society plays an oversight role that serves as a check for local officials' misbehavior. As Huang accurately notes,

While in every political system bureaucratic agents tend to distort the information that they pass to their political masters in order to place themselves in a good light, the problem is alleviated in democracies through "decentralized oversight", which enables citizen interest groups to check up on government actions (Huang 2005: 5)

China's prospects for a vibrant civil society as described above might be higher in the future given the reform of the Cadre Personnel System in 2000 which placed greater emphasis in public opinion as a criterion to evaluate the officials' performance (Whiting 2004: 105). But even this would not suffice for sound civil society participation, unless the complex NGO registration process -which includes a $\$ 12000$ USD fee, finding an organizational spon-

10. Vice-Premier Wu Yi was appointed Health Minister after his predecessor Zhang Wenkang was ousted for his mismanagement of the SARS crisis. Wu's impulse to significant change in the AIDS policy structure has been attributed to her "can-do" leadership style. However, to many analysts of Chinese politics her drive cannot be abstracted from the leadership transition happening at that time. Thus, her determination for change has more to do with President $\mathrm{Hu}$ Jintao's strategy to affirm his leadership vis a vis former President Jiang Zemin by appointing his allies to crucial positions where he could advance his own policy preferences without breaking with the hard liners of the Jiang era. 
sor, and the approval from the Civil Affairs Department- is removed and the social forces are freed from the government control.

\section{Three Promising Communication Strategies}

As part of a broader initiative to prevent HIV/AIDS; soap operas, TV commercials and documentaries can play a decisive role by spreading short-powerful messages that might incite behavioral changes. Research-based, written in minority languages, and using both traditional and locally composed music, soap operas intend to appeal and be relevant to local people in the areas where they are broadcasted. The fact that they are based on real life-experiences ensures that programmes are culturally and linguistically relevant to the audience. ${ }^{11}$

TV campaigns on the other hand are a new format for sounding the prevailing ignorance about HIV/AIDS in the Chinese society. Given its larger audience and the time constraints, the commercials use short-touching messages that force people to think about their behavior, analyze it and change it. ${ }^{12}$ Finally, a recent wave of underground documentaries reporting the human suffering of HIV has arrived in China and has immediately captivated the public. With a thoughtful selection of powerful stories, the documentaries aim to reach a narrower audience hungry for an overt and deep coverage of the epidemic. Commenting on Chen Weijun's documentary To Live is Better Than to Die, Dong Yueling confesses that:

11. In the Yunnan province, "Life of Tragedies" -produced in the Jingpo language- and "The Weeping Jade Dragon Snow Mountain" -produced in the Naxi language- address individual behavior change as well as the cultural, spiritual/religious and social context of individuals. The dramatizations explore the decisions facing young minority women today, and the implications of those decisions. The use of local languages is based on UNESCO's assessment that one of the main barriers to preventive education in the region is the vast number of distinct languages from different language families (Blume 2006). On the other hand, Bai Xing (ordinary people) is the story of Ershui, a character that has been distinguished by his promiscuity and contracts HIV. His story is used as a vehicle for informing the public about modes of transmission (mainly unprotected heterosexual relations with multiple partners). Lu Ye, the female protagonist, leads the villagers to accept Ershui and to treat him with compassion. Viewers are thus reassured that caring for an HIV-positive person and treating him kindly entail no risks of transmission (Singhal et. al. 2003: 331).

12. For an example of a preventive campaign, see: http://www.youtube.com/watch?v=KQPeNDf A51I\&mode $=$ related\&search $=$

http://www.youtube.com/watch?v=6a1dXNGv7Us\&mode=related\&search= 
Chen Weijun never himself expected that the documentary he made with his DVD camera, a film about the ordinary lives of a peasant family, would shake people to their cores and bring him international acclaim. In Wuhan, I climb to the seventh floor of an apartment block, dripping with perspiration as I approach the Chen home. In the disorder of the sitting room, I watch this documentary, "To Live is better than to die". After I've watched the 80-minutes, my feet and hands are icy. I struggle for breat (Dong 2004).

Her coverage would not be surprising if it was not featured in the China Youth Daily even while the documentary was banned. This is one of the few cases where courageous journalists risked their freedom to hail public attention on a sensitive topic like HIV/AIDS ${ }^{13}$.

However, as Blume accurately points out, none of these formats can expect effective results if they are not combined with other educational activities:

A radio soap opera alone is not enough to bring about behavior change. In my opinion, spin-off activities or the cooperation with other initiatives or organizations should already be addressed during the planning stage (Blume 2006)

In the future, if the Chinese media wants to take responsibility in fighting against HIV/AIDS, a closer relation with education organizations will be needed. But in order to do so, total flexibility on the part of the Chinese government to broadcast these formats without impediment will be a permanent condition. China's first condom TV-advertisement cancelation in 1999 on grounds that sex products should not be advertised, together with the removal of a billboard promoting condom use in Wuhan in 2000 due to government officials' beliefs that condoms would lead to the abandonment of sexual morality, go exactly in the opposite direction (Rosenthal 2000). The paranoia that characterizes the PRC and its leaders has prevented them from realizing the benefits of a differential treatment to these formats. Given the current time limits to broadcast stories, the media cannot criticize the Chinese government effectively. Therefore, their potential to threaten the PRC's stability is very low. Through these formats, the Chinese leadership could both reduce criticism and achieve some improvements in the war against

13. For other documentaries on HIV/AIDS in China see: Ruby Yang's "The Blood of Yingzhou District", http://www.youtube.com/watch?v=CJx18Ynuzck, and Lucy Liu's "Three Needles", http://www.youtube.com/watch?v=Ofh6A1mO0Oo\&mode=related\&search 
HIV/AIDS. This is not to say that keeping the censorship over the Chinese media is a correct measure, but only that in the case of an authoritarian regime some flexibility with certain channels of communication can prevent humanitarian disasters that would otherwise be shameful not only for the regime but for all humankind.

\section{Conclusions}

This article has focused on China's response to a pandemic that dangerously evolved into a security threat. Very few cases in the world experience such a dramatic shift but are quite frequent in authoritarian regimes such as China's. As demonstrated above, the Chinese leadership's obsession with economic growth as a means to secure power creates perverse incentives for central and local authorities to hide epidemics. Not surprising, HIV/AIDS, SARS and Avian flu were all hidden from the public eye until this strategy no longer served the purpose of holding the Chinese Communist Party in power. As sadly as it may sounds, increasing the cost of humanitarian catastrophes for the Chinese government is hard to foresee in the near future unless social forces -mass media included-are freed from anachronistic measures that prevent citizens from making the authorities accountable for their wrongdoings.

On the one side restrained by government controls and on the other side constrained by its economic survival, the Chinese media's coverage of HIV/ AIDS is extremely reduced but not impossible. Given the interconnection of HIV prevalence and the lack of a national health care system there might be an opportunity for "tangential" coverage by linking the necessity of health care with providing services to thousands of HIV-infected Chinese citizens. In the mean time, even if the media does not make such a connection, NGOs can utilize the link in order to promote HIV-prevention in the public agenda, though repeated crackdowns on NGOs performing that same activity considerably reduces this option. The media could also improve their HIV/AIDS reporting by developing a resource centre where journalists could access reliable and current information such as quotes, statistics and other resources required for balanced reporting (Settle et. al. 2005). As for the alternative formats like soap operas and TV commercials, an important step would be paying competitive salaries to those involved in entertaining education campaigns; that way famous artists would participate in the soap operas and thus it would increase their audience (Singhal et. al. 2003: 311). 
Given the conservative character of the Chinese media, HIV could also be effectively addressed on the Internet given its broad audience, flexibility and openness. In fact, as Singhal points out, the Internet is an excellent channel for HIV prevention,

[...] because it can reach target populations, especially in developing countries where an increasing number of young people use the internet at cybercafés and public access computer centers. The websites' anonymous nature of virtual interaction allows an open discussion of taboo topics creating a comfortable space for youth to regularly log on (Singhal et al. 2003: 300)

However as Southerland demonstrates, the finest internet controls imposed by the Chinese government inhibit such efforts:

Could it be that bloggers will now fill the gap and provide some of the investigative journalism that is missing from the equation? Unlikely, say leading Chinese journalists. China's leaders judge the news based upon whether it supports or undermines their power (Southerland 2007)

While the main reason for exerting control over the media is hiding sensitive issues that could undermine the Chinese Communist Party, the media is also responsible for the lack of information given the commercial orientation initiated after the reforms of 1994. In the short run, HIV/AIDS-control depends exclusively on individual journalists' determination and courage to keep the topic in the public eye. In 2005, Kristen Swain concluded that,

The elite media have an obligation to provide leadership in stopping the spread of disease and death. Some journalists accept responsibility for informing the public about AIDS, but most do not see public education as part of their role. However, the media have enormous potential to help stop the spread of AIDS if they could inform the public continuously and accurately about the true nature and scope of HIV risks around the world (Swain 2005: 261).

This paper considers that her conclusion still stands today. If HIV reaches the figure predicted by the Chinese government in 2010, the Chinese Media will undoubtedly be responsible for that, at least in part. The possibility to change this course rests in their hands. 


\section{References}

Bai, Ruoyun (2006), Media Restructuring, Commercialization and the Blitz of Television Entertainment in the New Millennium China Paper presented at the annual meeting of the International Communication Association, Sheraton New York, New York City, NY.

Blume, Claudia (2006), "Life of Tragedies: A Discussion of the Production of a Radio Soap Opera for HIV/AIDS Prevention in Yunnan, China", Glocal Times, Issue 4

Brown, Tim and Peter Xenos (1994), "AIDS in Asia: The Gathering Storm", Asia Pacific Issues, No. 16, August., Honolulu: East-West Center.

Choi K et al. (2003) "Emerging HIV-1 epidemic in China in men who have sex with men", Lancet, 361(9375); pp. 2125-6.

Choi KH et al. (2007) "The influence of social and sexual networks in the spread of HIV and syphilis among men who have sex with men in Shanghai, China", Journal of Acquired Immune Deficiency Syndromes, 45(1) pp. 77-84.

Dong Yueling (2004), "Freezing Point", China Youth Daily, 30 Jun

Eberstadt, Nicholas (2002), "The future of AIDS”, Foreign Affairs, November/ December.

Gang Lin (2003), Party Media Reform in China, Personal Statement for Roundtable "Freedom of the Press in China after SARS: Reform and Retrenchment", Woodrow Wilson International Center for Scholars, September 22.

Gill, Bates, Jennifer Chang and Sarah Palmer (2002), "China's HIV Crisis", Foreign Affairs, Vol. 81, Issue 2, pp.96-110.

Hebden, Sophie (2006), "African and Asian media must report more on AIDS”, SciDev.Net, 3 Aug.

HRW (2003), Locked Doors: The Human Rights of People Living with HIV/AIDS in China, Vol. 15, No. 7

Huang, Yanzhong (2005), The Politics of HIV/AIDS in China, Paper prepared for the Freeman Asian Studies Symposium on China "Changing Perspectives on China: New Debates, Approaches and Challenges in $21^{\text {st }}$ Century Asian Studies", Lake Forest College, March 31.

Hwang, Ann (2001), "AIDS has arrived in India and China", World Watch, Jan-Feb

Lewis, Orion (2004), The Media in State-Society Relations: Does Commercialization Change Political Control,? Paper presented at the annual meeting of 
The Midwest Political Science Association, Palmer House Hilton, Chicago, Illinois, Apr 15

Li, Xiaoming et al. (2004), "HIV/STD Risk Behaviors and Perceptions among Rural-to-Urban Migrants in China”, AIDS Education and Prevention, Vol. 16, No. 6, pp. 538-556.

Lu F et al. (2006). HIV/AIDS epidemic in China: Increasing or decreasing? Abstract MOPE0462. XVI International AIDS Conference. 13-18 August. Toronto.

Lule, Jack (2005), “AIDS and the News Media: 1980-2005”, Critical Studies in Media Communication, Vol. 22, No. 3, pp.256 - 257.

Ma X et al. (2006) "Possible rise in HIV prevalence among men who have sex with men (MSM) in Beijing", Abstract MOPE0526. XVI International AIDS Conference. 13-18 August. Toronto.

Ma, Ringo (2005), "Media, crisis, and SARS: An introduction", Asian Journal of Communication, Vol.15, No. 3, pp.241-246.

Min, Wu (2006), "Framing AIDS in China: A Comparative Analysis of US and Chinese Wire News Coverage of HIV/AIDS in China", Asian Journal of Communication, Vol. 16, No. 3, pp. 251-272.

Ministry of Health China (2006). 2005 update on the HIV/AIDS epidemic and response in China. Beijing: Ministry of Health China, UNAIDS, WHO.

Rosenthal, Elizabeth (2000), "Scientists Warn of Inaction as AIDS spreads in China", The New York Times, 2 August.

Settle, Edmund and Bill Valentino (2005), "Media must rethink AIDS coverage", China Daily, 24 Aug, p.4

Shirk, Susan L. (2007), China: Fragile Superpower, New York: Oxford University Press

Singhal, Arvind and Everett M. Rogers (2003), Combating AIDS: Communication Strategies in Action, New Delhi: Sage.

Southerland, Dan (2007), “China's Media Controls: Could bloggers make a difference?”, China Brief, Vol. 7, Issue 8, April, pp. 4-6.

Swain, Kristen Alley (2005), "Approaching the Quarter-Century Mark: AIDS Coverage and Research Decline as Infection Spreads", Critical Studies in Media Communication, Vol. 22, No. 3, pp. 258 - 262.

Tao X et al. (2004) "Survey of related high risk behaviors of MSM in Shenzhen city", Modern Preventive Medicine, Vol. 31, pp. 247-8. 
UNAIDS (2004), A Joint Assessment Report of HIV/AIDS Prevention, Treatment and Care in China, Beijing: UNAIDS/State Council AIDS Working Committee Office/National Center for AIDS/STD Prevention and Control. UNAIDS (2007), AIDS Epidemic Update, Geneva: UNAIDS/WHO.

Whines, Michael (2010), "China Lifts Ban on Visitors Who Are H.I.V. Positive", The New York Times, 28 April

Whiting, Susan H. (2004), "The Cadre Evaluation System at the Grass Roots: The Paradox of Party Rule", in Barry Naughton and Dali L. Yang eds., Holding China Together: Diversity and National Integration in the Post-Deng Era. Cambridge: Cambridge University Press, pp. 101-119

Yang, Ruoqian (2002), "Curbing AIDS Proliferation, No Time for China to Delay Any Longer”, Renmin Ribao, 24 July

Zhu TF et al. (2005), "High risk populations and HIV-1 infection in China", Cell Research, 15(11-12), pp. 852-7. 